\title{
Observations of bromine monoxide transport in the Arctic sustained on aerosol particles
}

\author{
Peter K. Peterson ${ }^{1}$, Denis Pöhler ${ }^{2}$, Holger Sihler ${ }^{2,3}$, Johannes Zielcke ${ }^{2}$, Stephan General ${ }^{2}$, Udo Frieß $^{2}$, Ulrich Platt ${ }^{2,3}$, \\ William R. Simpson ${ }^{4}$, Son V. Nghiem ${ }^{5}$, Paul B. Shepson ${ }^{6}$, Brian H. Stirm ${ }^{7}$, Suresh Dhaniyala ${ }^{8}$, Thomas Wagner ${ }^{3}$, \\ Dana R. Caulton ${ }^{9}$, Jose D. Fuentes ${ }^{10}$, and Kerri A. Pratt ${ }^{1,11}$ \\ ${ }^{1}$ Department of Chemistry, University of Michigan, Ann Arbor, MI, USA \\ ${ }^{2}$ Institute of Environmental Physics, University of Heidelberg, Heidelberg, Germany \\ ${ }^{3}$ Max Planck Institute for Chemistry, Mainz, Germany \\ ${ }^{4}$ Department of Chemistry and Biochemistry and Geophysical Institute, \\ University of Alaska Fairbanks, Fairbanks, Alaska, USA \\ ${ }^{5}$ Jet Propulsion Laboratory, California Institute of Technology, Pasadena, CA, USA \\ ${ }^{6}$ Department of Chemistry, Department of Earth, Planetary, and Atmospheric Sciences, and \\ Purdue Climate Change Research Center, Purdue University, West Lafayette, IN, USA \\ ${ }^{7}$ School of Aviation and Transportation Technology, Purdue University, West Lafayette, IN, USA \\ ${ }^{8}$ Department of Mechanical and Aeronautical Engineering, Clarkson University, Potsdam, NY, USA \\ ${ }^{9}$ Department of Civil and Environmental Engineering, Princeton University, Princeton, NJ, USA \\ ${ }^{10}$ Department of Meteorology, The Pennsylvania State University, University Park, PA, USA \\ ${ }^{11}$ Department of Earth and Environmental Sciences, University of Michigan, Ann Arbor, MI, USA
}

Correspondence to: Kerri A. Pratt (prattka@umich.edu)

Received: 21 December 2016 - Discussion started: 23 February 2017

Revised: 18 May 2017 - Accepted: 23 May 2017 - Published: 22 June 2017

\begin{abstract}
The return of sunlight in the polar spring leads to the production of reactive halogen species from the surface snowpack, significantly altering the chemical composition of the Arctic near-surface atmosphere and the fate of long-range transported pollutants, including mercury. Recent work has shown the initial production of reactive bromine at the Arctic surface snowpack; however, we have limited knowledge of the vertical extent of this chemistry, as well as the lifetime and possible transport of reactive bromine aloft. Here, we present bromine monoxide $(\mathrm{BrO})$ and aerosol particle measurements obtained during the March 2012 BRomine Ozone Mercury EXperiment (BROMEX) near Utqiaġvik (Barrow), AK. The airborne differential optical absorption spectroscopy (DOAS) measurements provided an unprecedented level of spatial resolution, over 2 orders of magnitude greater than satellite observations and with vertical resolution unable to be achieved by satellite methods, for $\mathrm{BrO}$ in the Arctic. This novel method provided quantitative identification of a $\mathrm{BrO}$ plume, between $500 \mathrm{~m}$ and $1 \mathrm{~km}$ aloft, moving
\end{abstract}

at the speed of the air mass. Concurrent aerosol particle measurements suggest that this lofted reactive bromine plume was transported and maintained at elevated levels through heterogeneous reactions on colocated supermicron aerosol particles, independent of surface snowpack bromine chemistry. This chemical transport mechanism explains the large spatial extents often observed for reactive bromine chemistry, which impacts atmospheric composition and pollutant fate across the Arctic region, beyond areas of initial snowpack halogen production. The possibility of $\mathrm{BrO}$ enhancements disconnected from the surface potentially contributes to sustaining $\mathrm{BrO}$ in the free troposphere and must also be considered in the interpretation of satellite $\mathrm{BrO}$ column observations, particularly in the context of the rapidly changing Arctic sea ice and snowpack. 


\section{Introduction}

With the return of sunlight in the polar spring, production of reactive halogen species radically changes the chemical processes in the Arctic atmospheric boundary layer (Simpson et al., 2007b). Bromine radical chemistry, in particular, is implicated in widespread episodic depletion of boundary layer ozone (Barrie et al., 1988; McConnell et al., 1992; Simpson et al., 2007b) and altered oxidation of atmospheric pollutants, including mercury (Schroeder et al., 1998; Steffen et al., 2008). Satellite observations have given a coarse depiction of the spatial extent of these events (e.g., Richter et al., 1998; Wagner and Platt, 1998; Sihler et al., 2012; Choi et al., 2012), showing that millions of square kilometers are affected by this chemistry. However, many uncertainties regarding the initiation of this halogen chemistry and its vertical distribution, as well as the transport and sustained recycling of reactive halogens aloft, remain (Simpson et al., 2015).

Satellite-based observations have shown large plumes (1000 s of kilometers) of $\mathrm{BrO}$ commonly occurring over sea ice regions in the spring (Wagner and Platt, 1998; Richter et al., 1998). While these plumes could potentially be stratospheric in origin or related to variations in tropopause height (Theys et al., 2009; Salawitch et al., 2010), a variety of tropospheric BrO retrievals (e.g., Theys et al., 2011; Sihler et al., 2012; Koo et al., 2012), which use various techniques to subtract the stratospheric $\mathrm{BrO}$ contribution and calculate a tropospheric $\mathrm{BrO}$ column, continue to show these large $\mathrm{BrO}$ plumes over the Arctic. However, during both the ARCTAS and ARCPAC campaigns, flight measurements showed enhancements in tropospheric $\mathrm{BrO}$ above the convective boundary layer (e.g., Salawitch et al., 2010; Choi et al., 2012), potentially sustained on aerosol particles (e.g., Parrella et al., 2012; Schmidt et al., 2016), suggesting that some of this $\mathrm{BrO}$ column may not be due to boundary layer halogen activation chemistry in sea ice regions.

Ground-based measurements also show a relationship between $\mathrm{BrO}$ and sea ice regions (Simpson et al., 2007a); however, the low short-term correlation between the time an air mass spends in sea ice regions and the amount of $\mathrm{BrO}$ observed suggests that, while an air mass origin in sea ice regions is important, other environmental factors control the release of reactive bromine (Peterson et al., 2016). Given the short lifetime of $\mathrm{BrO}$ under sunlit conditions, heterogeneous reactions are required to explain the amount of reactive bromine observed in the Arctic spring (McConnell et al., 1992; Platt and Hönninger, 2003). While the snowpack provides an abundant surface for these reactions near the ground, both ground-based (Frieß et al., 2011; Peterson et al., 2015) and airborne (McElroy et al., 1999; PradosRoman et al., 2011; Choi et al., 2012) observations have shown active halogen chemistry also occurring aloft. Concurrent observations of aerosol particle extinction and $\mathrm{BrO}$ by Frieß et al. (2011) showed increases in near-surface $\mathrm{BrO}$ occurring concurrently with high wind speeds and increased aerosol extinction. They interpret this as wind-abraded snow dispersed aloft, which provides additional surface area for this chemistry to occur. This process occurred concurrently with snowpack-driven halogen chemistry. In contrast, Peterson et al. (2015) observed that, during the spring of 2012, aerosol particle extinction did not depend solely on wind speed, and events occurred with $\mathrm{BrO}$ aloft in the absence of enhancements in near-surface aerosol particle extinction. Thus, the mechanism for sustaining such halogen chemistry aloft, independent of the snowpack, remains unknown. While aerosol particles represent a potential surface for these reactions to take place aloft (Fan and Jacob, 1992), there is currently no observational evidence for this phenomenon occurring solely aloft, independent of concurrent snowpack-driven halogen activation chemistry.

During the March 2012 BRomine Ozone Mercury EXperiment (BROMEX) near Utqiagivik (Barrow), Alaska, we investigated the activation (i.e., conversion of $\mathrm{Br}^{-}$to reactive bromine, e.g., $\mathrm{Br}$ atoms, $\mathrm{BrO}$, or $\mathrm{HOBr}$; Fig. 1) and subsequent transport of reactive bromine with a combination of satellite, airborne, and ground-based measurements (Nghiem et al., 2013). While the spatial extent of this reactive bromine chemistry can be characterized from satellite measurements at a spatial resolution of tens of kilometers, the vertical distribution of $\mathrm{BrO}$ in the atmospheric boundary layer cannot be determined via satellite, complicating identification of the source, mechanism of initial activation, subsequent transport scales, and chemical transformation of the reactive bromine. In contrast, ground-based differential optical absorption spectroscopy (DOAS) enables determination of the amount of $\mathrm{BrO}$ both near the surface and in the lowest $2 \mathrm{~km}$ of the atmosphere with high temporal resolution (Frieß et al., 2011; Peterson et al., 2015), while airborne DOAS measurements allow the determination of spatial distribution of $\mathrm{BrO}$ with $100 \mathrm{~m}$ vertical and horizontal resolution (General et al., 2014), enabling detailed observation of moving BrO plumes. The combination of these techniques in the current study allowed observations of the evolution of the vertical and horizontal distribution of reactive bromine chemistry with an unprecedented level of detail, enabling identification of the mechanisms driving the transport of reactive bromine aloft.

\section{Methods}

\subsection{DOAS measurements}

Airborne $\mathrm{BrO}$ measurements were made using the Purdue University Airborne Laboratory for Atmospheric Research (ALAR, Nghiem et al., 2016). The 13 March 2012 flight took off from the Utqiagivik airport located at $71.2853^{\circ} \mathrm{N}$, $156.7658^{\circ} \mathrm{W}$. ALAR carried the Heidelberg Airborne Imaging DOAS Instrument (HAIDI), allowing for simultaneous 


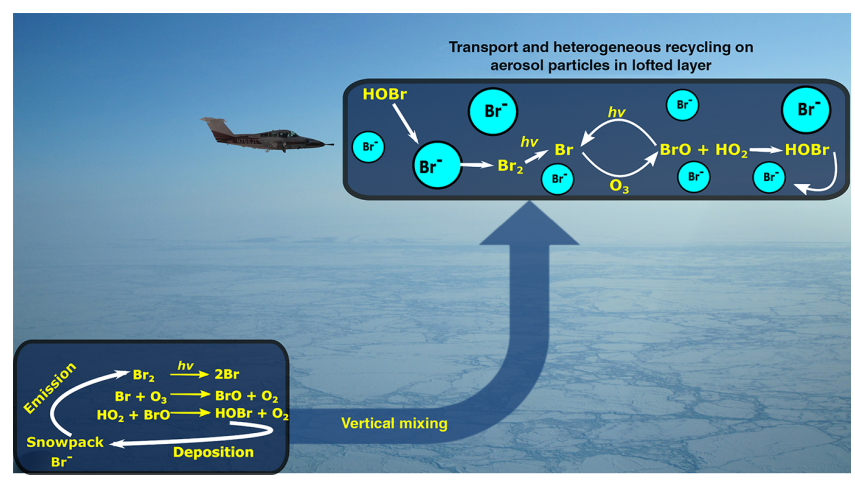

Figure 1. Overview of processes observed in this study. Bromide $\left(\mathrm{Br}^{-}\right)$is converted to reactive bromine (e.g., $\mathrm{Br}_{2}, \mathrm{BrO}$, and $\mathrm{HOBr}$ ) through heterogeneous reactions occurring in the surface snowpack leading to the release of $\mathrm{Br}_{2}$ into the overlying atmosphere. This $\mathrm{Br}_{2}$ undergoes photolysis, creating bromine atoms and leading to ozone depletion. As increased mixing is observed, the bromine-enriched air mass moves aloft. On the day of the flight, we observed sustained BrO levels in a lofted layer concurrent with aerosol particles, indicating heterogeneous recycling of reactive bromine aloft, decoupled from the initial snowpack activation processes.

measurements in both scanning nadir view and limb view (General et al., 2014). The initial DOAS fitting of the HAIDI spectra and subsequent analysis of the nadir viewing measurements have been described extensively in previous literature (Pratt et al., 2013; General et al., 2014). Limb viewing measurements allowed for the retrieval of $\mathrm{BrO}$ and aerosol particle extinction profiles (e.g., Prados-Roman et al., 2011) during ALAR ascent and descent. After the initial DOAS fitting, the limb measurements of $\mathrm{O}_{4}$ and $\mathrm{BrO}$ were used in a two-step optimal estimation procedure to retrieve $\mathrm{BrO}$ profiles (Frieß et al., 2011). Averaging kernels, error bars, and further details of these retrievals are given in the Supplement. Satellite-based $\mathrm{BrO}$ lower-tropospheric vertical column densities (LT-VCDs) were determined using Level 1 GOME-2 data provided by EUMETSAT. The stratospheric subtraction to obtain a LT-VCD was completed using previously published techniques (Sihler et al., 2012).

Ground-based (multiple-axis) MAX-DOAS measurements were conducted at three sites during BROMEX (Nghiem et al., 2016). The instrument at Utqiagivik was placed on top of the Barrow Arctic Research Consortium (BARC) building, located at $71.325^{\circ} \mathrm{N}, 156.668^{\circ} \mathrm{W}$, with a viewing azimuth of $27^{\circ}$ east of true north. Additional MAXDOAS instruments were deployed at two sea ice locations as part of the Icelander platform, an autonomous platform designed to be rapidly deployed via helicopter and to conduct chemical and meteorological measurements at remote locations (Peterson et al., 2015). The first Icelander (IL1) was deployed east of Utqiagivik at $71.355^{\circ} \mathrm{N}, 155.668^{\circ} \mathrm{W}$, with a view azimuth of $2^{\circ}$ east of true north, while the sec- ond Icelander (IL2) was deployed to the west at $71.274^{\circ} \mathrm{N}$, $157.395^{\circ} \mathrm{W}$, with a view azimuth of $12^{\circ}$ east of true north.

These MAX-DOAS data were analyzed using previously published techniques (Frieß et al., 2011; Peterson et al., 2015). Briefly, solar spectra at telescope elevation angles of $1,2,5,10$, and $20^{\circ}$ were analyzed using temporally located zenith spectra as a reference for DOAS fitting to retrieve differential slant columns (dSCDs) of $\mathrm{BrO}$ and $\mathrm{O}_{4}$. These $\mathrm{dSCDs}$ were used to retrieve mole fractions of $\mathrm{BrO}$ from the surface up to $2 \mathrm{~km}$, with optimal estimation assuming an a priori $\mathrm{BrO}$ profile with $10 \mathrm{pmol} \mathrm{mol}^{-1}$ at the surface exponentially decaying with a scale height of $250 \mathrm{~m}$. The retrieved profiles represent 20 pieces of information; however, the typical degrees of freedom for signal in our retrievals range between 1 and 2 independent pieces of information. Thus, rather than using the retrieved profile, we report a VCD in the lowest $200 \mathrm{~m}$, and if visibility permits, a LT-VCD for 0-2 km (Peterson et al., 2015).

\subsection{Chemical ionization mass spectrometry}

Measurements of $\mathrm{Br}_{2}, \mathrm{BrO}$, and $\mathrm{HOBr}$ were conducted using chemical ionization mass spectrometry (CIMS) at a site $\left(71.275^{\circ} \mathrm{N}, 156.6405^{\circ} \mathrm{W}\right) \sim 5 \mathrm{~km}$ inland and southeast of Utqiagivik, AK (Peterson et al., 2015; Shepson, 2014). Using $\mathrm{I}\left(\mathrm{H}_{2} \mathrm{O}\right)_{n}^{-}$reagent ions, $\mathrm{Br}_{2}$ was monitored as $\mathrm{I}^{79} \mathrm{Br}^{81} \mathrm{Br}^{-}$ (287 amu) and $\mathrm{I}^{81} \mathrm{Br}^{81} \mathrm{Br}^{-}$(289 amu), BrO as $\mathrm{I}^{79} \mathrm{BrO}^{-}$ (222 amu) and $\mathrm{I}^{81} \mathrm{BrO}^{-}(224 \mathrm{amu})$, and $\mathrm{HOBr}$ as $\mathrm{IH}^{79} \mathrm{BrO}^{-}$ (223 amu) and $\mathrm{IH}^{81} \mathrm{BrO}^{-}$(225 amu). For 11-13 March 2012, the limit of detection for $1 \mathrm{~h}$ averaging is estimated at $0.4 \mathrm{pmol} \mathrm{mol}^{-1}$ for $\mathrm{Br}_{2}, \mathrm{BrO}$, and $\mathrm{HOBr}$, with the associated uncertainties calculated to be $\left(14 \%+0.4 \mathrm{pmol} \mathrm{mol}^{-1}\right)$, $\left(63 \%+0.4 \mathrm{pmol} \mathrm{mol}^{-1}\right)$, and $\left(50 \%+0.4 \mathrm{pmol} \mathrm{mol}^{-1}\right)$, respectively. Additional sampling details are provided in the Supplement.

\subsection{Aerosol particle measurements}

Size-resolved aerosol particle number concentrations were measured with $6 \mathrm{~s}$ temporal resolution using a Grimm 1.109 optical particle counter (Grimm Aerosol Technik GmbH), which measured particles from 0.25 to $32 \mu \mathrm{m}$ in 31 size bins. A size-resolved model of inlet transmission was used to correct the measured number concentrations for expected aircraft inlet losses as a function of particle diameter. Details of this model are given in the Supplement. After correcting for inlet efficiency, only particles up to $4 \mu \mathrm{m}$ (optical diameter) were considered in further analysis. Surface area concentrations were estimated assuming that all measured particles were spherical with a diameter equal to the midpoint of the size bin.

\subsection{Envisat ASAR sea ice images}

Satellite radar images were acquired by the Advanced Synthetic Aperture Radar (ASAR) aboard the ESA's Environ- 


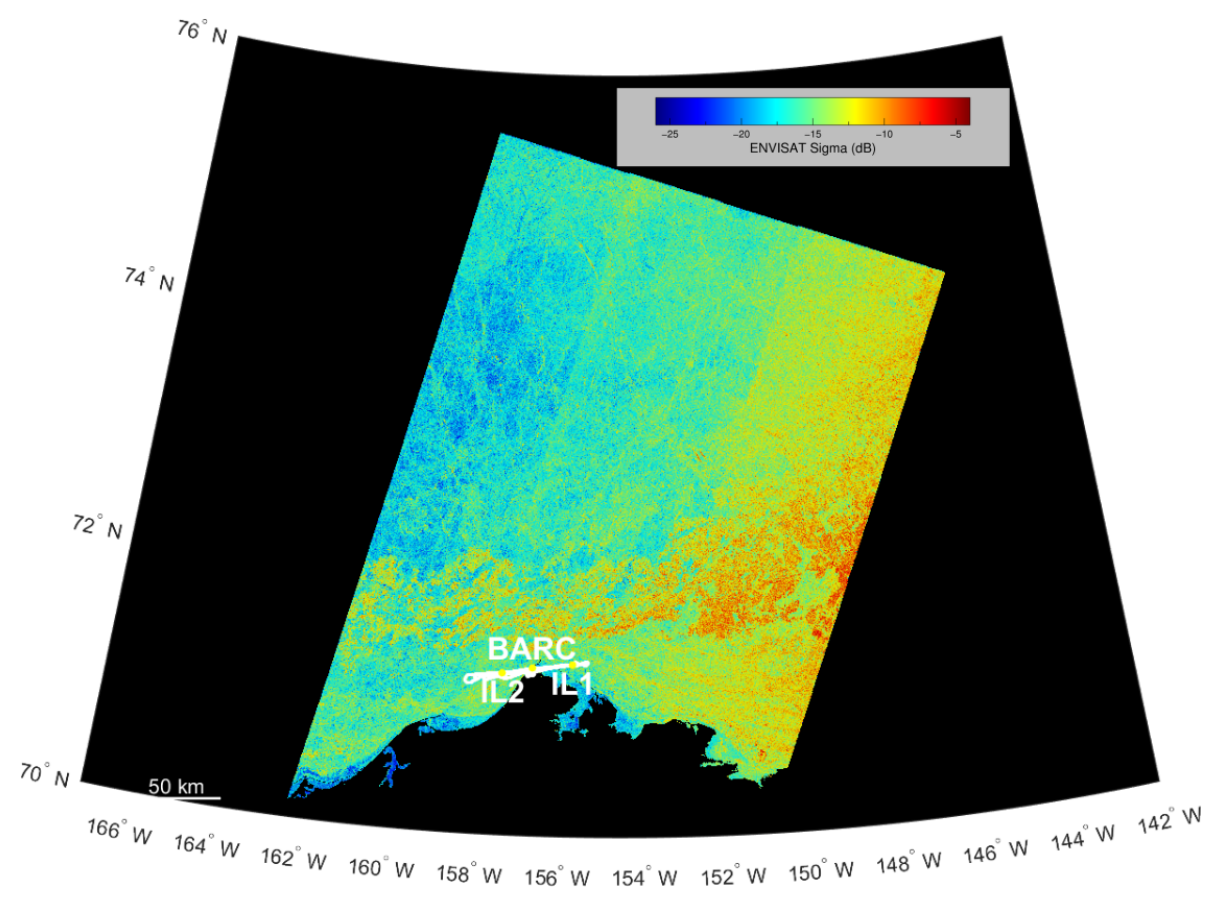

Figure 2. Sea ice imagery from Envisat Advanced Synthetic Aperture Radar (ASAR) backscatter data (Sigma in dB). Flight track and measurement locations include Barrow Arctic Research Consortium (BARC) building, Icelander 1 (IL1), and Icelander 2 (IL2). Multi-year ice is shown in darker red, and first-year ice is shown in orange to green and blue colors.

mental Satellite (Envisat) to support BROMEX. For the period of analysis in this paper, an Envisat ASAR scene was obtained on 11 March 2012 over the BROMEX study domain, including the Chukchi Sea and the Beaufort Sea (Fig. 2). This ASAR scene was collected in the Wide Swath Mediumresolution mode (ASA_WSM_1P) with the horizontal polarization. ASA_WSM_1P has a geometric resolution of approximately $150 \mathrm{~m}$ by $150 \mathrm{~m}$ with a pixel spacing of $75 \mathrm{~m}$ by $75 \mathrm{~m}$ over a swath width of $400 \mathrm{~km}$ along a stripe of $4000 \mathrm{~km}$ in the maximum extent (European Space Agency, 2007). In the data processing, the precise orbits were used before calibration and terrain correction to achieve accurate backscatter with an excellent geolocation. The ASAR data allowed an excellent observation of sea ice with the all-weather capability regardless of solar lighting and cloud cover conditions.

\subsection{Supporting ozone and meteorological measurements}

Ozone mole fractions and meteorological data were obtained from the NOAA Global Monitoring Division (GMD) site near Utqiagivik, Alaska. Twice-daily meteorological soundings (03:00 and 15:00 AKST) were conducted at the Utqiagivik airport. The $72 \mathrm{~h}$ backward air mass trajectories were calculated using the NOAA Hybrid Single Particle Lagrangian Integrated Trajectory (HYSPLIT) model (Stein et al., 2015). These trajectories were calculated in an ensemble configuration using an arrival height of $750 \mathrm{~m}$ a.g.l. (above ground level) and $1^{\circ}$ GDAS meteorology. Meteorological measurements aboard ALAR were obtained using a Best Air Turbulence (BAT) probe (Garman et al., 2006). Airborne $\mathrm{O}_{3}$ measurements were not available during this flight.

\section{Results and discussion}

Here we show observations of an intense synoptic-scale halogen activation event observed at Utqiagivik, Alaska, on 1113 March. We describe the details of this event chronologically and show the process by which snowpack $\mathrm{Br}_{2}$ production and evolving boundary layer stability later led to the decoupled recycling of reactive bromine on aerosol particles aloft (Fig. 1).

\subsection{Initial snowpack-driven bromine activation}

During BROMEX, GOME-2 satellite observations of BrO on 11 March 2012 showed an intense synoptic-scale halogen activation event over the northern coast of Alaska and Canada, including Utqiaġvik, Alaska (Fig. 3a). Ground-based $\mathrm{BrO}$ measurements at both sea ice and tundra sites near Utqiagivik show that this event initiated near the snowpack (Figs. 3b, 4), with 30-40\% of the observed $\mathrm{BrO}$ column in the lowest $200 \mathrm{~m}$. At Utqiagivik, winds were out of the northeast with speeds below $6 \mathrm{~m} \mathrm{~s}^{-1}$ (Fig. 5c), which likely enabled movement of air from the snowpack to the overlying atmosphere through wind pumping (Peterson et al., 2015). How- 


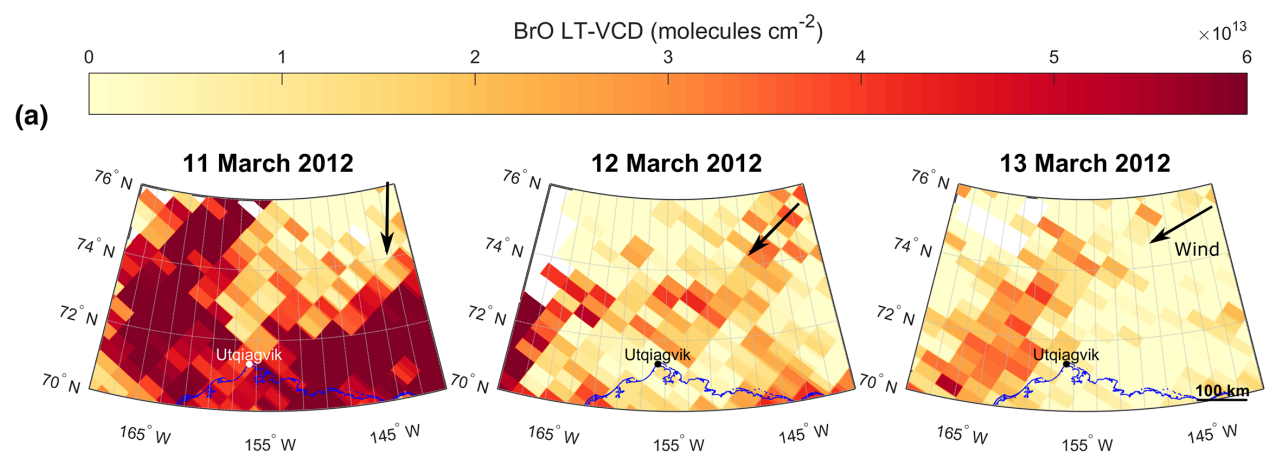

(b)

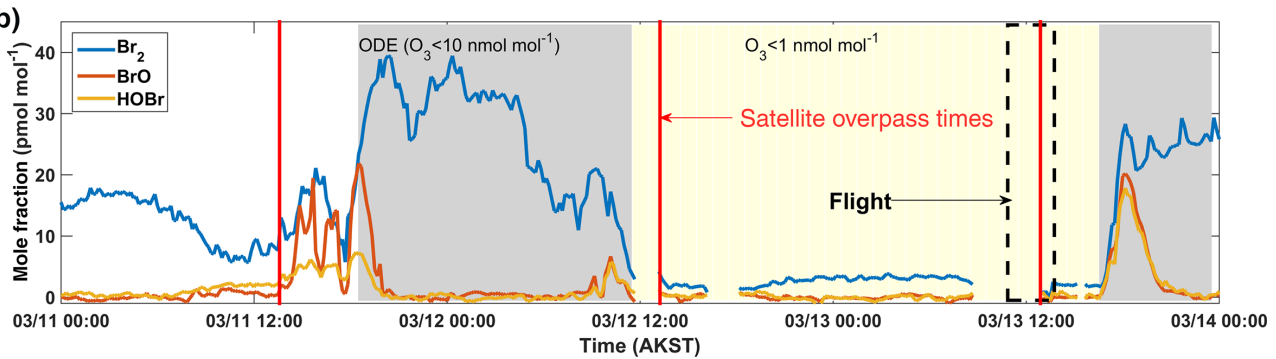

Figure 3. Summary of (a) satellite-based $\mathrm{BrO}$ observations over northern Alaska and (b) ground-based reactive bromine measurements at the Utqiagivik tundra site. (a) BrO lower-tropospheric vertical column densities (LT-VCDs) from the GOME-2 satellite are shown from 11 to 13 March 2012, with the location of Utqiagvik, Alaska, denoted. The top portion of the map is the Arctic Ocean, while the bottom portion is snow-covered tundra. The wind direction at Utqiagivik is shown with black arrows. (b) Gas-phase bromine species $\left(\mathrm{Br}_{2}\right.$, $\mathrm{BrO}$, and $\left.\mathrm{HOBr}\right)$ mole fractions measured with chemical ionization mass spectrometry are shown for 11-13 March 2012. Data gaps represent time periods of separate experiments (Pratt et al., 2013). Times when an ODE $\left(\mathrm{O}_{3}<10 \mathrm{nmol} \mathrm{mol}^{-1}\right)$ was observed at Utqiagvik are shaded in gray; times when ozone was titrated $\left(\mathrm{O}_{3}<1 \mathrm{nmol} \mathrm{mol}^{-1}\right)$ to the point of inhibiting $\mathrm{BrO}$ formation are shaded in yellow. The flight time is outlined with a black box, and the times of satellite overpasses are denoted with red lines.

ever, the wind speeds were too low to induce blowing snow (Jones et al., 2009; Yang et al., 2010). Further evidence of snowpack-sourced reactive bromine is provided by observed enhanced near-surface $(1 \mathrm{~m})$ mole fractions of $\mathrm{Br}_{2}, \mathrm{BrO}$, and $\mathrm{HOBr}$ (Fig. 3). Together, these findings indicate that this event originated at the snow surface, which is consistent with a snowpack source of $\mathrm{Br}_{2}$ (Pratt et al., 2013).

At 17:00 AKST on 11 March, near-surface ozone mole fractions sharply decreased at Utqiagivik from 20 to $8 \mathrm{nmol} \mathrm{mol}^{-1}$ over a $1 \mathrm{~h}$ time period (Fig. $5 \mathrm{~b}$ ). This rapid ozone loss cannot be explained solely by bromine chemistry occurring at Utqiagivik (Hausmann and Platt, 1994) and likely indicated the advection of a boundary layer ozone depletion event (ODE) into the study area. By 20:00 AKST ozone levels had fallen to near-zero levels (Fig. 5b), which has been shown to inhibit $\mathrm{BrO}$ production (Helmig et al., 2012), and is reflected in the $\mathrm{BrO}$ observations during this study (Fig. 3b). Inhibition of $\mathrm{BrO}$ formation also hindered the formation of $\mathrm{HOBr}$, as shown in Fig. 3b, halting the heterogeneous recycling (Fig. 1) needed to sustain high levels of reactive bromine in the Arctic boundary layer (Fan and Jacob, 1992). The lack of recycling leads to the observed decrease in $\mathrm{Br}_{2}$ production (Pratt et al., 2013), effectively ending snowpack production of reactive bromine (Fig. $3 \mathrm{~b}$ ). This reduction in reactive bromine near the surface is also observed via decreasing $\mathrm{BrO}$ column densities observed from GOME-2 on 12 and 13 March (Fig. 3a). Continuous determination of the vertical distribution of $\mathrm{BrO}$ by concurrent ground-based DOAS measurements showed that the reduction in reactive bromine near the surface was accompanied by movement of $\mathrm{BrO}$ aloft on 12 March, transitioning to $\mathrm{BrO}$ being observed exclusively aloft on 13 March (Figs. 3b, 4).

\subsection{Movement of $\mathrm{BrO}$ aloft}

Given that the most probable initial source of the observed reactive bromine was the surface snowpack, as discussed above, subsequent observations of $\mathrm{BrO}$ aloft raise the question of how the $\mathrm{BrO}$ was lofted to $\sim 750 \mathrm{~m}$ where the plume was observed. Previously proposed mechanisms for enhancing the vertical extent of $\mathrm{BrO}$ events include blowing snow events, where high wind speeds lead to activation of bromine from dispersed snow aloft (Yang et al., 2010; Jones et al., 2009; Frieß et al., 2011); wind pumping events, where increased ventilation of the snowpack in a turbulent atmosphere potentially allows the propagation of $\mathrm{BrO}$ aloft $(\mathrm{Pe}-$ terson et al., 2015; Toyota et al., 2014); uplifting of bromineenriched air masses due to synoptic-scale meteorological conditions (Frieß et al., 2004; Begoin et al., 2010); and the opening of sea ice leads, which are associated with enhanced 

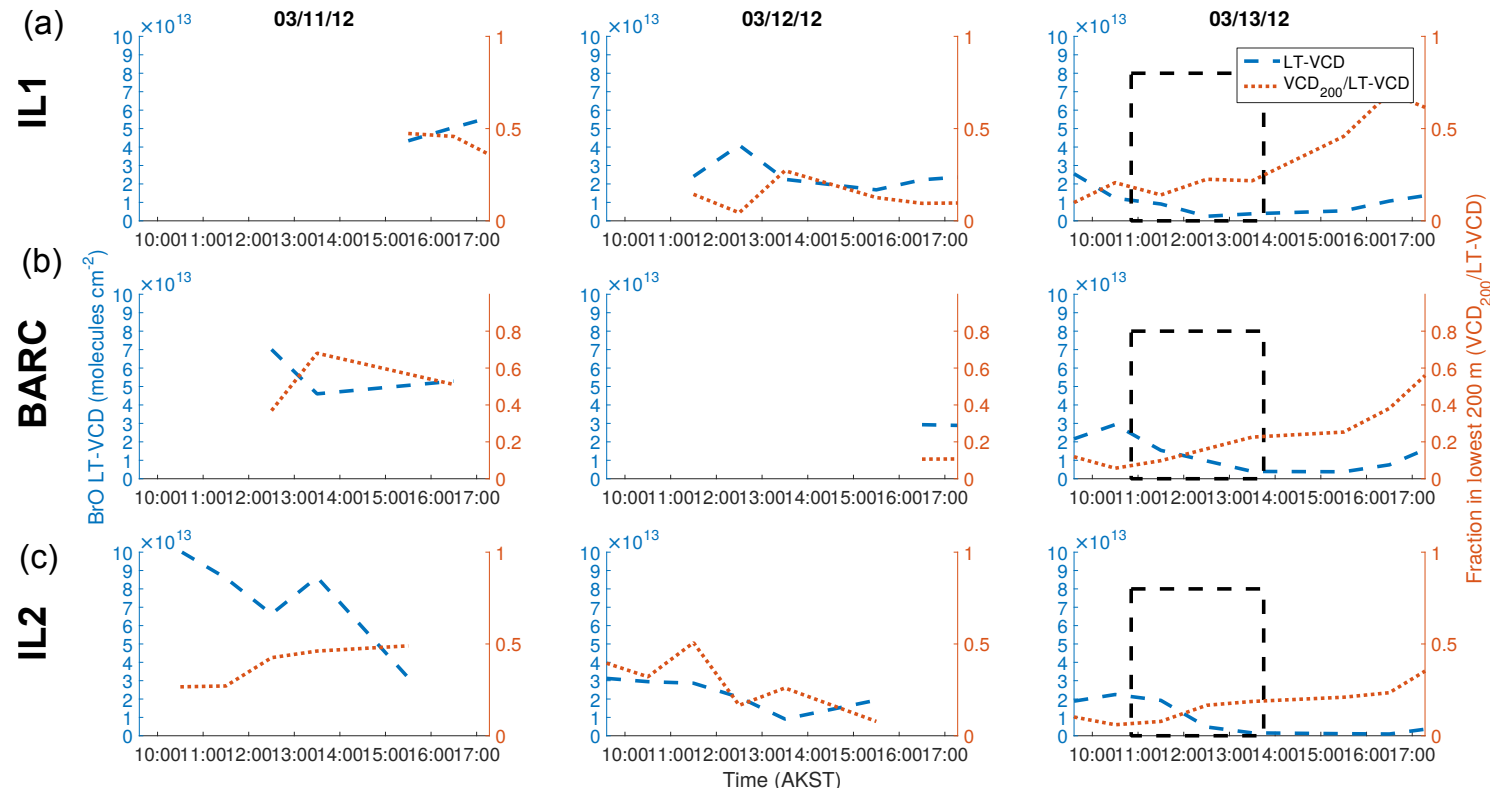

Figure 4. Summary of ground-based MAX-DOAS BrO observations near Barrow; all times are local. Observations are from IL1 (a), the BARC building (b), and IL2 (c). The blue lines show the LT-VCD measured from the ground, and the red lines show the fraction in the lowest $200 \mathrm{~m}$. LT-VCDs are not shown when the degrees of freedom aloft is below 0.7 , indicating reduced visibility.
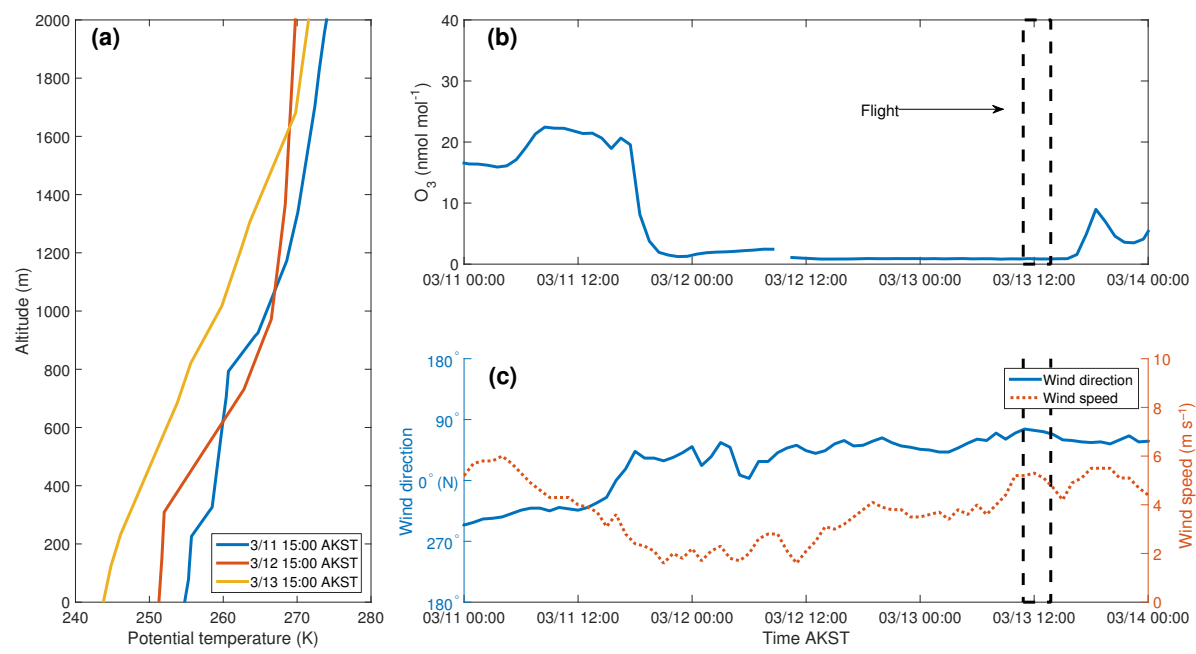

Figure 5. Meteorological and in situ ozone measurements at Utqiagivik. (a) Daytime soundings from the Utqiagivik airport. (b) Near-surface ozone mole fractions from the NOAA/GMD Barrow Observatory. (c) Wind speeds and directions from the NOAA/GMD Barrow Observatory. In panels (b) and (c), dashed rectangles indicate when the flight took place.

vertical mixing (Wagner et al., 2007; Moore et al., 2014) and have been proposed to lead to increases in $\mathrm{BrO}$ aloft (McElroy et al., 1999).

Backward air mass trajectories (Fig. 6) also suggest that the observed lofted bromine originated near the snowpack in sea ice regions as part of the large-scale activation event observed on 11 March. These trajectories, along with NCEP reanalysis data (Figs. 6, S4 in the Supplement) from 11 March are also consistent with the $\mathrm{BrO}$ plume being uplifted from the surface prior to arriving over Utqiagivik on 13 March. Sea ice imagery (Fig. 2) shows no indication of open sea ice leads near or upwind of Utqiagivik, ruling out local sea ice dynamics as an explanation for the presence of $\mathrm{BrO}$ aloft observed in this study. The vertical distribution of $\mathrm{BrO}$ is closely tied to atmospheric stability, with shallow layers associated with thermal inversions, where most of the $\mathrm{BrO}$ is in the lowest $200 \mathrm{~m}$, compared to well-mixed atmospheres, which allow for the propagation of $\mathrm{BrO}$ aloft, leading to a lower fraction of the observed $\mathrm{BrO}$ residing near the surface snowpack (Peterson et al., 2015). Despite the absence of leads, daily 

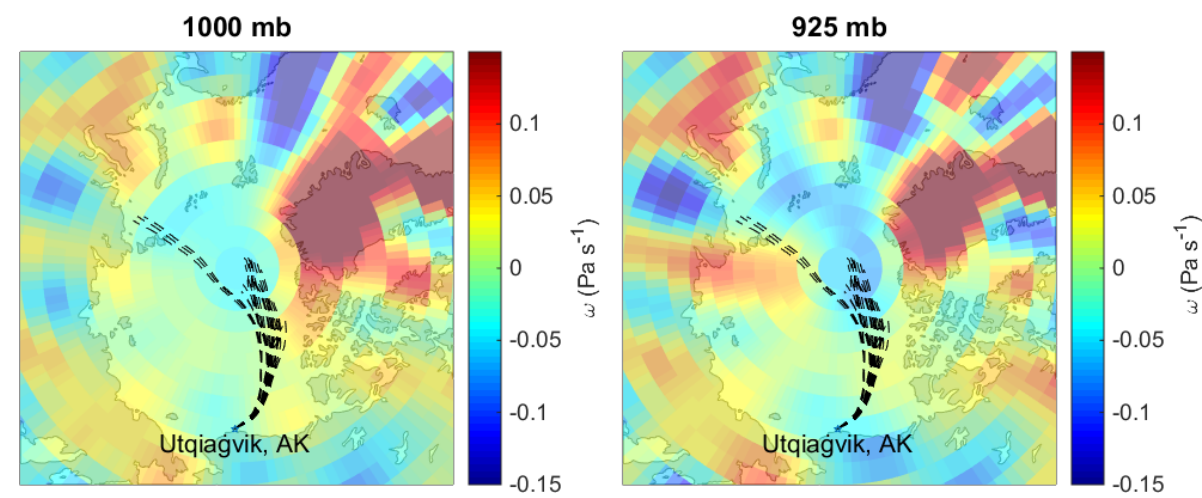

Figure 6. HYSPLIT backward air mass trajectories for the plume overlaid on daily averaged NCEP reanalysis data for 11 March 2012 . All panels show an ensemble of $2772 \mathrm{~h}$ trajectories arriving at Utqiagivik on 13 March 2012 at noon local time. The central trajectory had an arrival height of $750 \mathrm{~m}$. The ensemble is generated by offsetting the modeled meteorology used to calculate the trajectory by $1^{\circ}$ horizontally and $\sim 250 \mathrm{~m}$ vertically prior to running HYSPLIT. The blue regions on the map reflect regions where air was moving upward, while red regions reflect regions where air was moving downward.

meteorological soundings (Fig. 5a) from 11 and 12 March (15:00 AKST) at the Utqiagivik airport show increased atmospheric mixing, allowing $\mathrm{BrO}$ to propagate aloft prior to the day of the flight, as seen with the ground-based MAX-DOAS measurements (Fig. 4). On 13 March, the potential temperature profile at flight takeoff showed inhibited atmospheric mixing due to a surface-based inversion (Fig. 8), decoupling the chemistry occurring in the plume aloft from the snowpack.

\subsection{Observed transport of reactive bromine aloft}

On 13 March, individual satellite overpasses (Fig. 7a) showed a tropospheric $\mathrm{BrO}$ plume, moving to the west over Utqiagivik, linked to the event described above. Concurrently, airborne measurements probed both the vertical profile and horizontal distribution of this $\mathrm{BrO}$ plume from 10:53 to 13:33 AKST. Figure 9 shows that when the aircraft took off from Utqiagivik, $\mathrm{BrO}$ mole fractions were near zero at the surface and increased to $15-20 \mathrm{pmol} \mathrm{mol}^{-1}$ between $500 \mathrm{~m}$ and $1 \mathrm{~km}$ aloft, indicating that the $\mathrm{BrO}$ observed by the satellite during the flight corresponded to a lofted reactive bromine plume. Ground-based MAX-DOAS measurements at Utqiagivik and two sea ice sites in a linear array spanning $\sim 60 \mathrm{~km}$ also confirmed that the observed $\mathrm{BrO}$ remained aloft as the plume moved westward over the course of the flight (Fig. 7c). Similarly, near-surface measurements of $\mathrm{Br}_{2}, \mathrm{HOBr}$, and $\mathrm{BrO}$ (Fig. 3b) confirmed that little active halogen chemistry occurred above the snowpack surface on 13 March, and that any $\mathrm{BrO}$ observed during the flight time period was solely due to bromine activation chemistry occurring aloft.

Airborne transects (Fig. 7) enabled detailed characterization of the lofted $\mathrm{BrO}$ plume as it moved west. The largest observed $\mathrm{BrO}$ LT-VCD, within the lowest $\sim 2 \mathrm{~km}$, during each airborne transect ranged from 2.8 to
$3.3 \times 10^{13}$ molecules $\mathrm{cm}^{-2}$ (Fig. 7b). A linear fit of the plume peak position versus flight time (Fig. 7b) for the six plume transects $(R=0.97)$ showed that the $\mathrm{BrO}$ plume was moving westward with a velocity of $7 \mathrm{~m} \mathrm{~s}^{-1}$, consistent with measured wind speeds of $6-10.5 \mathrm{~m} \mathrm{~s}^{-1}$ to the west at altitudes of $500 \mathrm{~m}$ to $1 \mathrm{~km}$ during initial flight ascent (Fig. 8). The plume moving with the wind indicates that these observations reflect transport of a reactive bromine feature, rather than the plane flying over areas with variable amounts of recycling or primary bromine emission from the snowpack. The vertical profile of $\mathrm{BrO}$ obtained just prior to the end of the flight (Fig. 9) showed that the $\mathrm{BrO}$ plume was no longer present above Utqiagivik, consistent with ground-based and satellite observations (Fig. 7a, c).

\subsection{Role of aerosol particles}

During plume transport, the peak BrO LT-VCD observed during each transect did not decay during the flight, indicating sustained $\mathrm{BrO}$ levels of $\sim 20 \mathrm{pmol} \mathrm{mol}^{-1}$ (Fig. 9a). Examination of aerosol particle extinction vertical profiles shows that the beginning of the flight was marked by a lofted aerosol layer at the altitude of the $\mathrm{BrO}$ plume (Fig. 9b) over Utqiagivik. Like the $\mathrm{BrO}$ plume, this lofted aerosol layer was not observed over Utqiagivik at the end of the flight. The enhanced aerosol particle extinction aloft is consistent with observed enhancements in supermicron $(>1 \mu \mathrm{m})$ aerosol surface area concentrations at $800-900 \mathrm{~m}$ (Fig. 9c). During the two transects of the plume conducted in the altitude range where the $\mathrm{BrO}$ plume was observed, in situ aerosol particle measurements showed peaks in supermicron aerosol particle surface area concentrations occurring concurrently with peaks in $\mathrm{BrO}$. For the first transect, both measurements peaked at a longitude of $157.10^{\circ} \mathrm{W}$. For the second transect, the $\mathrm{BrO}$ peaked at a longitude of $157.31^{\circ} \mathrm{W}$, with supermicron aerosol particle surface area peaking at a longitude of 


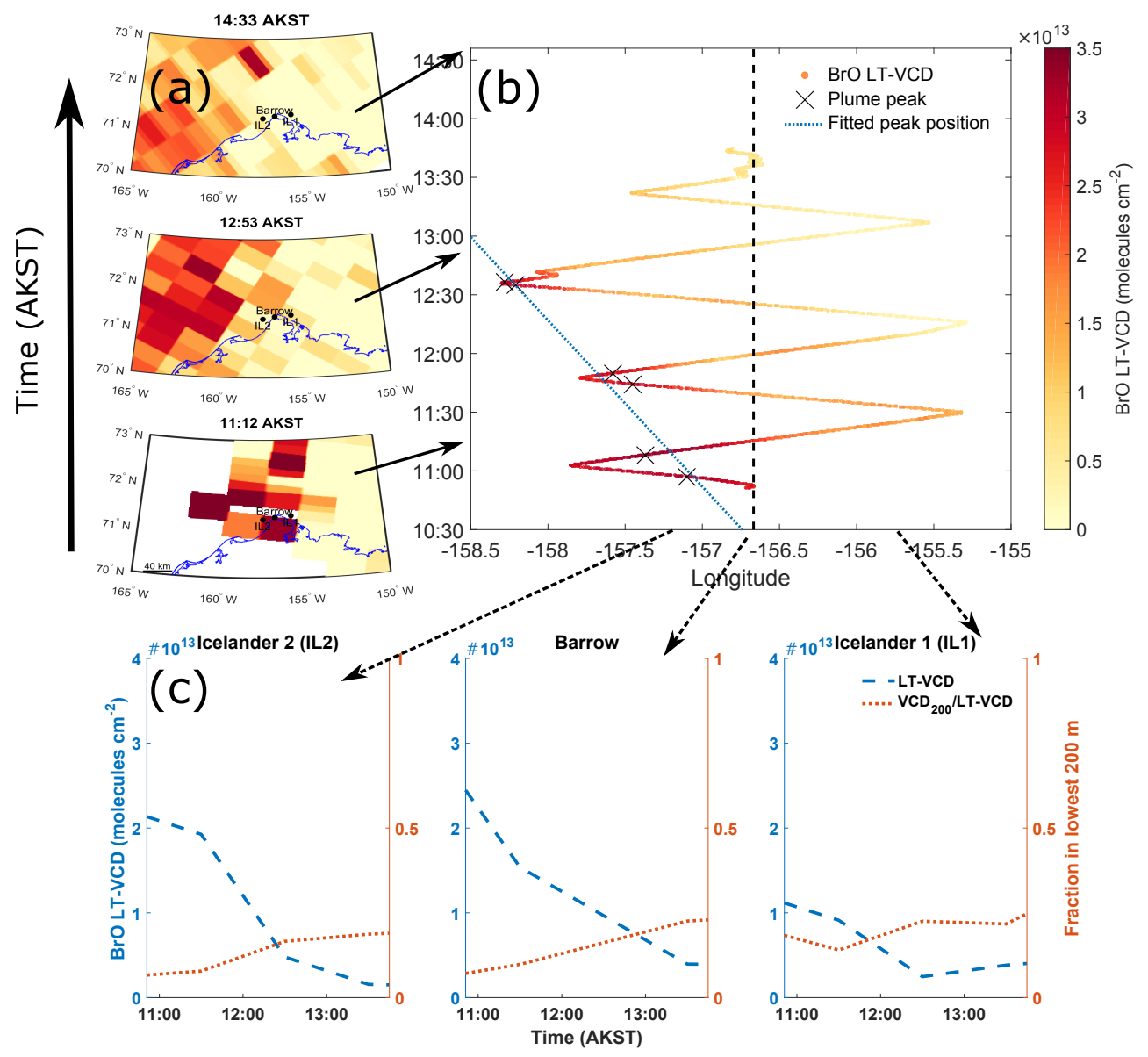

Figure 7. Summary of BrO plume motion over Utqiagivik on 13 March. (a) BrO plume motion from east to west as observed by individual overpasses of the GOME-2 satellite as well as the locations of ground-based measurement sites. The blue line denotes the Alaska coastline. (b) BrO plume motion as observed by airborne DOAS. The dashed black line indicates the longitude of Utqiagivik. The black crosses show the observed peak BrO positions for each transect, while the blue line gives the fitted plume peak location as a function of time. (c) Ground-based MAX-DOAS measurements at each site during the flight arranged from west to east.
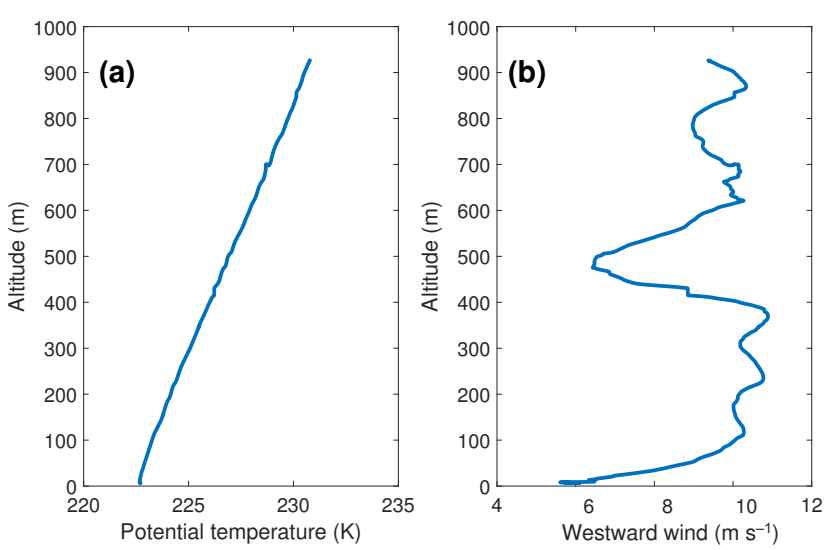

Figure 8. Potential temperature (a) and east-west component of wind speed profiles (b) from aircraft ascent on 13 March 2012 at 10:53 AKST. $157.36^{\circ} \mathrm{W}$, showing that the aerosol particle plume and $\mathrm{BrO}$ plume were moving together with the wind.

Over the course of this flight, submicron $(0.25-1.0 \mu \mathrm{m})$ aerosol particle number concentrations had a median value of $26.5 \mathrm{~cm}^{-3}$ with a standard deviation of $16.8 \mathrm{~cm}^{-3}$. At altitudes where the plume was observed, the variations in submicron aerosol particle number concentrations within and outside of the plume were not significantly different at the $95 \%$ confidence level (Smirnov, 1939). Supermicron $(>1.0 \mu \mathrm{m})$ aerosol particle number concentrations had a median value of $1.2 \mathrm{~cm}^{-3}$ with a standard deviation of $6.3 \mathrm{~cm}^{-3}$. In contrast to the submicron aerosol, the variability in supermicron aerosol particle number concentrations within and outside of the plume were significantly different at the $95 \%$ confidence level (Smirnov, 1939), with increasing supermicron aerosol surface area observed with increasing BrO LTVCDs (Fig. 10). This finding indicates that it is unlikely that variations in submicron aerosol particles were a primary 

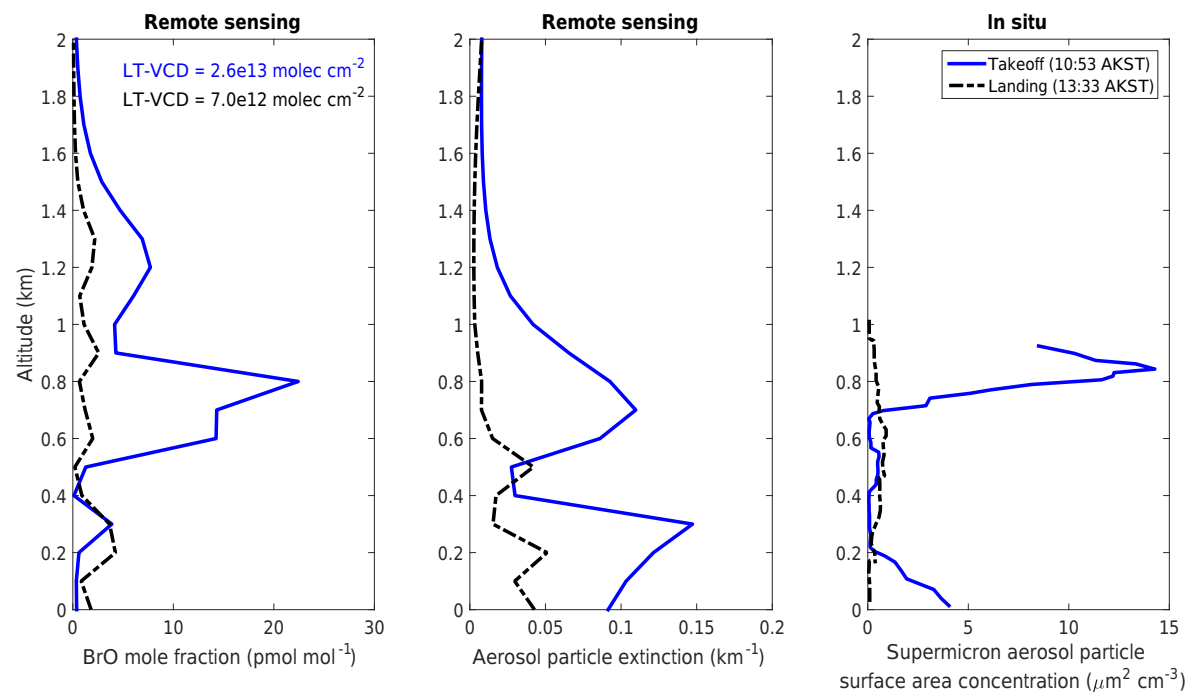

Figure 9. Vertical profiles of BrO mole fractions with the corresponding LT-VCD, aerosol particle extinction, and supermicron (1-4 $\mu \mathrm{m}$ optical diameter) aerosol particle surface area concentrations during takeoff and landing for the 13 March 2012 flight. Error bars on the remote sensing measurements have been omitted for clarity and are shown in the Supplement.

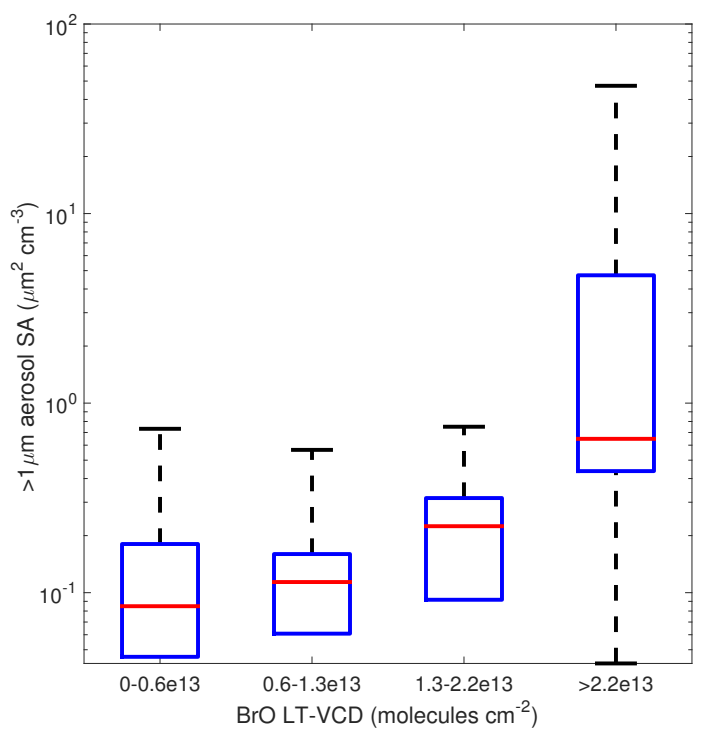

Figure 10. Box and whisker plot of supermicron particle surface area (SA) concentrations as a function of BrO LT-VCD. The red line represents the median, the blue box outlines the inner quartiles, and the whiskers represent the outer quartiles. In some cases, the difference between the lowest aerosol observation and the 25th percentile is too small to draw a lower whisker. These aerosol observations are restricted to altitudes where the plume was observed on takeoff and binned by dividing the $\mathrm{BrO}$ observations into quartiles.

controlling factor in the heterogeneous recycling of reactive bromine on particles aloft. However, within the $\mathrm{BrO}$ plume, it is likely that bromide propagated, through multiphase reactions and subsequent gas-particle partitioning, from supermicron aerosol particles to submicron aerosol particles (Hara et al., 2002) such that these particles may have also provided additional bromide-enriched surface area for heterogeneous recycling.

Previous studies have shown that the majority of supermicron particles in the springtime Arctic boundary layer are sea salt aerosol particles (Brock et al., 2011), which have the potential to be a source of reactive bromine (Fan and Jacob, 1992; Hara et al., 2002). Calculations of the reaction rate of $\mathrm{HOBr}$ with bromide based on the measured aerosol particle surface area concentrations and detailed in the Supplement suggest that the observed surface areas are likely sufficient to enable heterogeneous recycling of reactive bromine aloft. Recent literature (e.g., Yang et al., 2010; Jones et al., 2009) has suggested that wind-dispersed saline snow during high-wind events could be an important source of bromidecontaining aerosol particles. However, Peterson et al. (2015) showed that near-surface aerosol particle extinction is not dependent on near-surface wind speed at Utqiagivik and that episodes of enhanced particle extinction and $\mathrm{BrO}$ occur most often at lower wind speeds than typically cited as needed for blowing snow (Jones et al., 2009). Recent work by May et al. (2016) showed enhancements in supermicron sea salt aerosol particle number concentrations at Utqiagivik when wind speeds were greater than $4 \mathrm{~m} \mathrm{~s}^{-1}$ in the presence of open water or sea ice leads; these enhancements were not observed for closed ice conditions. While sea ice imagery (Fig. 2) shows no local lead activity, the lack of available sea ice imagery closer to the origin of the lofted layer (Fig.6) means we can not rule out the possibility of open leads and associated sea salt aerosol production where the observed lofted plume initiated. Given these limitations, we are unable to distinguish between a blowing snow source from consoli- 
dated sea ice and sea salt aerosol production from open leads as the source of the sea salt aerosol particles sustaining the $\mathrm{BrO}$ plume.

These coincident observations of an aerosol layer and $\mathrm{BrO}$ recycling aloft suggest that heterogeneous reactions on these aerosol particles played a key role in sustaining the observed enhanced levels of $\mathrm{BrO}$ aloft. Although this mechanism was previously proposed (McConnell et al., 1992; Fan and Jacob, 1992), our measurements constitute the first direct observation of this process occurring aloft, decoupled from the snowpack. Further ground-based measurements over the entirety of the BROMEX campaign have confirmed that the presence of aerosol particles aloft is a necessary but not sufficient condition to observe BrO aloft (Simpson et al., 2017).

\section{Conclusions}

The Arctic is currently undergoing rapid changes, including loss of perennial sea ice (Maslanik et al., 2011) and decreasing snow depth in sea ice regions (Blanchard-Wrigglesworth et al., 2015), both of which impact atmospheric composition through multiphase halogen chemistry (Simpson et al., 2007b). During BROMEX, the horizontal and vertical distribution of reactive bromine, in the form of $\mathrm{BrO}$, was quantified by airborne DOAS at unprecedented spatial resolution, over 2 orders of magnitude higher than satellite-based measurements. While a pan-Arctic-scale view of $\mathrm{BrO}$ can be obtained from satellites, this three-dimensional view of the $\mathrm{BrO}$ spatial extent, obtained for the first time in the Arctic, combined with higher temporal resolution compared to satellites, provided a process-level view of bromine activation. As summarized in Fig. 1, a synoptic-scale $\mathrm{BrO}$ event was observed together with snowpack bromine activation, releasing reactive bromine into the Arctic boundary layer. Evolving boundary layer stability allowed the reactive bromine to propagate aloft, where it underwent sustained transport enabled by recycling on aerosol particles independent of snowpack-driven halogen activation. The observation of aerosol recycling of reactive bromine, enabling the transport of a lofted $\mathrm{BrO}$ plume, provides a mechanism by which active halogen chemistry alters the fate and transport of atmospheric pollutants far beyond the immediate area where snowpack-sourced halogen activation occurs. This mechanism also provides a means of sustaining bromine chemistry in the free troposphere, potentially explaining previous observations of $\mathrm{BrO}$ in the Arctic free troposphere (e.g., Salawitch et al., 2010; Choi et al., 2012). This chemical transport mechanism is likely prevalent throughout the springtime Arctic, and the identification of this phenomenon improves our ability to evaluate changes in atmospheric composition related to rapidly changing Arctic sea ice.
Data availability. Data from the BROMEX field campaign are accessible at https://nex.nasa.gov/nex/projects/1388/ (Nghiem et al., 2016; Shepson, 2014) and/or by contacting the corresponding author.

\section{The Supplement related to this article is available online at https://doi.org/10.5194/acp-17-7567-2017-supplement.}

Author contributions. PKP and KAP led data integration, analysis, and interpretation. PKP prepared the initial version of the paper and figures. PKP and WRS conducted the ground-based $\mathrm{BrO}$ measurements with assistance from UF, JZ, and UP. PBS, DP, SG, JZ, KAP, and BHS conducted the aircraft-based measurements. HS and TW provided the satellite-based BrO measurements. SVN provided the sea ice measurements. KAP and PBS conducted the CIMS measurements. KAP, PKP, SD, and JDF contributed to the aerosol data collection and analysis. DRC contributed to the analysis of aircraftbased meteorological measurements. SVN led the 2012 field campaign along with PBS and WRS. All authors reviewed and commented on the paper.

Competing interests. The authors declare that they have no competing financial interests.

Acknowledgements. Financial support for this work was provided by the NASA Earth Science Research Program (NNX14AP44G). Funding for the airborne measurements was provided by NASA Cryospheric Sciences Program (CSP) as a part of the NASA Interdisciplinary Research on Arctic Sea Ice and Tropospheric Chemical Change (09-IDS09-31). The development and construction of the HAIDI instrument was funded by the Deutsche Forschungsgemeinschaft (DFG) within the Priority Program (SPP) no. 1294 "HALO" (DFG PF-384 7/1 and 7/2). The research at the University of Alaska Fairbanks (UAF) was supported by the Department of Chemistry and Biochemistry, NASA CSP, and the National Science Foundation (NSF) (ARC-1023118). The research at the Jet Propulsion Laboratory, California Institute of Technology, was supported by the NASA CSP and the Atmospheric Composition Program. During the BROMEX campaign, Kerri A. Pratt was supported by a NSF Postdoctoral Fellowship in Polar Regions Research (PLR-1103423). The authors acknowledge the NOAA Air Resources Laboratory for the provision of the HYSPLIT transport and dispersion model used in this publication. Alexei Rozanov (IUP Bremen) is thanked for providing the SCIATRAN radiative transfer code. Steve Walsh (UAF) is thanked for assistance with construction and deployment of the Icelander platforms. Kyle Custard (Purdue University), David Tanner (Georgia Tech), and Greg Huey (Georgia Tech) are thanked for assistance with CIMS measurements. National Centers for Environmental Prediction (NCEP) reanalysis data were provided by the Physical Sciences Division, Earth System Research Laboratory, NOAA (http://www.esrl.noaa.gov/psd/). GOME-2 level 1 data were provided by EUMETSAT. We thank Pablo Clemente-Colón and Christopher Jackson of the US National Ice Center for their help in accessing the Envisat ASAR data, and Lisa Nguyen at 
the Jet Propulsion Laboratory for the SAR data processing and geolocation.

Edited by: Jan W. Bottenheim

Reviewed by: two anonymous referees

\section{References}

Barrie, L. A., Bottenheim, J. W., Schnell, R. C., Crutzen, P. J., and Rasmussen, R. A.: Ozone destruction and photochemical reactions at polar sunrise in the lower Arctic atmosphere, Nature, 334, 138-141, https://doi.org/10.1038/334138a0, 1988.

Begoin, M., Richter, A., Weber, M., Kaleschke, L., Tian-Kunze, X., Stohl, A., Theys, N., and Burrows, J. P.: Satellite observations of long range transport of a large $\mathrm{BrO}$ plume in the Arctic, Atmos. Chem. Phys., 10, 6515-6526, https://doi.org/10.5194/acp10-6515-2010, 2010.

Blanchard-Wrigglesworth, E., Farrell, S. L., Newman, T., and Bitz, C. M.: Snow cover on Arctic sea ice in observations and an Earth System Model, Geophys. Res. Lett., 42, 10342-10348, https://doi.org/10.1002/2015GL066049, 2015.

Brock, C. A., Cozic, J., Bahreini, R., Froyd, K. D., Middlebrook, A. M., McComiskey, A., Brioude, J., Cooper, O. R., Stohl, A., Aikin, K. C., de Gouw, J. A., Fahey, D. W., Ferrare, R. A., Gao, R.-S., Gore, W., Holloway, J. S., Hübler, G., Jefferson, A., Lack, D. A., Lance, S., Moore, R. H., Murphy, D. M., Nenes, A., Novelli, P. C., Nowak, J. B., Ogren, J. A., Peischl, J., Pierce, R. B., Pilewskie, P., Quinn, P. K., Ryerson, T. B., Schmidt, K. S., Schwarz, J. P., Sodemann, H., Spackman, J. R., Stark, H., Thomson, D. S., Thornberry, T., Veres, P., Watts, L. A., Warneke, C., and Wollny, A. G.: Characteristics, sources, and transport of aerosols measured in spring 2008 during the aerosol, radiation, and cloud processes affecting Arctic Climate (ARCPAC) Project, Atmos. Chem. Phys., 11, 24232453, https://doi.org/10.5194/acp-11-2423-2011, 2011.

Choi, S., Wang, Y., Salawitch, R. J., Canty, T., Joiner, J., Zeng, T., Kurosu, T. P., Chance, K., Richter, A., Huey, L. G., Liao, J., Neuman, J. A., Nowak, J. B., Dibb, J. E., Weinheimer, A. J., Diskin, G., Ryerson, T. B., da Silva, A., Curry, J., Kinnison, D., Tilmes, S., and Levelt, P. F.: Analysis of satellite-derived Arctic tropospheric BrO columns in conjunction with aircraft measurements during ARCTAS and ARCPAC, Atmos. Chem. Phys., 12, 12551285, https://doi.org/10.5194/acp-12-1255-2012, 2012.

European Space Agency: Envisat ASAR Product Handbook, http://envisat.esa.int/handbooks/asar/CNTR.html (last access: 1 September 2016), 2007.

Fan, S.-M. and Jacob, D. J.: Surface ozone depletion in Arctic spring sustained by bromine reactions on aerosols, Nature, 359, 522-524, https://doi.org/10.1038/359522a0, 1992.

Frieß, U., Hollwedel, J., König-Langlo, G., Wagner, T., and Platt, U.: Dynamics and chemistry of tropospheric bromine explosion events in the Antarctic coastal region, J. Geophys. Res., 109, D06305, https://doi.org/10.1029/2003JD004133, 2004.

Frieß, U., Sihler, H., Sander, R., Pöhler, D., Yilmaz, S., and Platt, U.: The vertical distribution of $\mathrm{BrO}$ and aerosols in the Arctic: Measurements by active and passive differential optical absorption spectroscopy, J. Geophys. Res., 116, D00R04, https://doi.org/10.1029/2011JD015938, 2011.
Garman, K. E., Hill, K. A., Wyss, P., Carlsen, M., Zimmerman, J. R., Stirm, B. H., Carney, T. Q., Santini, R., and Shepson, P. B.: An Airborne and Wind Tunnel Evaluation of a Wind Turbulence Measurement System for Aircraft-Based Flux Measurements, J. Atmos. Ocean. Tech., 23, 1696-1708, https://doi.org/10.1175/JTECH1940.1, 2006.

General, S., Pöhler, D., Sihler, H., Bobrowski, N., Frieß, U., Zielcke, J., Horbanski, M., Shepson, P. B., Stirm, B. H., Simpson, W. R., Weber, K., Fischer, C., and Platt, U.: The Heidelberg Airborne Imaging DOAS Instrument (HAIDI) - a novel imaging DOAS device for 2-D and 3-D imaging of trace gases and aerosols, Atmos. Meas. Tech., 7, 3459-3485, https://doi.org/10.5194/amt-7-3459-2014, 2014.

Hara, K., Osada, K., Matsunaga, K., Iwasaka, Y., Shibata, T., and Furuya, K.: Atmospheric inorganic chlorine and bromine species in Arctic boundary layer of the winter/spring, J. Geophys. Res., 107, 4361, https://doi.org/10.1029/2001JD001008, 2002.

Hausmann, M. and Platt, U.: Spectroscopic measurement of bromine oxide and ozone in the high Arctic during Polar Sunrise Experiment 1992, J. Geophys. Res., 99, 25399, https://doi.org/10.1029/94JD01314, 1994.

Helmig, D., Boylan, P., Johnson, B., Oltmans, S., Fairall, C., Staebler, R., Weinheimer, A., Orlando, J., Knapp, D. J., Montzka, D. D., Flocke, F., Frieß, U., Sihler, H., and Shepson, P. B.: Ozone dynamics and snow-atmosphere exchanges during ozone depletion events at Barrow, Alaska, J. Geophys. Res.-Atmos., 117, D20303, https://doi.org/10.1029/2012JD017531, 2012.

Jones, A. E., Anderson, P. S., Begoin, M., Brough, N., Hutterli, M. A., Marshall, G. J., Richter, A., Roscoe, H. K., and Wolff, E. W.: BrO, blizzards, and drivers of polar tropospheric ozone depletion events, Atmos. Chem. Phys., 9, 4639-4652, https://doi.org/10.5194/acp-9-4639-2009, 2009.

Koo, J.-H., Wang, Y., Kurosu, T. P., Chance, K., Rozanov, A., Richter, A., Oltmans, S. J., Thompson, A. M., Hair, J. W., Fenn, M. A., Weinheimer, A. J., Ryerson, T. B., Solberg, S., Huey, L. G., Liao, J., Dibb, J. E., Neuman, J. A., Nowak, J. B., Pierce, R. B., Natarajan, M., and Al-Saadi, J.: Characteristics of tropospheric ozone depletion events in the Arctic spring: analysis of the ARCTAS, ARCPAC, and ARCIONS measurements and satellite BrO observations, Atmos. Chem. Phys., 12, 9909-9922, https://doi.org/10.5194/acp-12-9909-2012, 2012.

Maslanik, J., Stroeve, J., Fowler, C., and Emery, W.: Distribution and trends in Arctic sea ice age through spring 2011, Geophys. Res. Lett., 38, L13502, https://doi.org/10.1029/2011GL047735, 2011.

May, N. W., Quinn, P. K., McNamara, S. M., and Pratt, K. A.: Multiyear study of the dependence of sea salt aerosol on wind speed and sea ice conditions in the coastal Arctic, J. Geophys. Res.-Atmos., 121, 9208-9219, https://doi.org/10.1002/2016JD025273, 2016.

McConnell, J. C., Henderson, G. S., Barrie, L., Bottenheim, J., Niki, H., Langford, C. H., and Templeton, E. M. J.: Photochemical bromine production implicated in Arctic boundary-layer ozone depletion, Nature, 355, 150-152, https://doi.org/10.1038/355150a0, 1992.

McElroy, C. T., McLinden, C. A., and McConnell, J. C. J.: Evidence for bromine monoxide in the free troposphere during the Arctic polar sunrise, Nature, 397, 338-341, https://doi.org/10.1038/16904, 1999. 
Moore, C. W., Obrist, D., Steffen, A., Staebler, R. M., Douglas, T. A., Richter, A., and Nghiem, S. V.: Convective forcing of mercury and ozone in the Arctic boundary layer induced by leads in sea ice, Nature, 506, 81-84, https://doi.org/10.1038/nature12924, 2014.

Nghiem, S. V., Clemente-Colón, P., Douglas, T., Moore, C., Obrist, D., Perovich, D. K., Pratt, K. A., Rigor, I. G., Simpson, W., Shepson, P. B., Steffen, A., and Woods, J.: Studying Bromine, Ozone, and Mercury Chemistry in the Arctic, Eos T. Am. Geophys. Un., 94, 289-291, https://doi.org/10.1002/2013EO330002, 2013.

Nghiem, S. V., Platt, U., Shepson, P. B., and Simpson, W. R.: Implications of Arctic Sea Ice Reduction on Tropospheric Bromine, Ozone, and Mercury Chemical Processes, Transport, and Distribution, NASA Earth Exch, available from: https://nex.nasa.gov/ nex/projects/1388/, last access: 1 September 2016.

Parrella, J. P., Jacob, D. J., Liang, Q., Zhang, Y., Mickley, L. J., Miller, B., Evans, M. J., Yang, X., Pyle, J. A., Theys, N., and Van Roozendael, M.: Tropospheric bromine chemistry: implications for present and pre-industrial ozone and mercury, Atmos. Chem. Phys., 12, 6723-6740, https://doi.org/10.5194/acp12-6723-2012, 2012.

Peterson, P. K., Simpson, W. R., Pratt, K. A., Shepson, P. B., Frieß, U., Zielcke, J., Platt, U., Walsh, S. J., and Nghiem, S. V.: Dependence of the vertical distribution of bromine monoxide in the lower troposphere on meteorological factors such as wind speed and stability, Atmos. Chem. Phys., 15, 2119-2137, https://doi.org/10.5194/acp-15-2119-2015, 2015.

Peterson, P. K., Simpson, W. R., and Nghiem, S. V.: Variability of bromine monoxide at Barrow, Alaska, over four halogen activation (March-May) seasons and at two onice locations, J. Geophys. Res.-Atmos., 121, 1381-1396, https://doi.org/10.1002/2015JD024094, 2016.

Platt, U. and Hönninger, G.: The role of halogen species in the troposphere, Chemosphere, 52, 325-38, https://doi.org/10.1016/S0045-6535(03)00216-9, 2003.

Prados-Roman, C., Butz, A., Deutschmann, T., Dorf, M., Kritten, L., Minikin, A., Platt, U., Schlager, H., Sihler, H., Theys, N., Van Roozendael, M., Wagner, T., and Pfeilsticker, K.: Airborne DOAS limb measurements of tropospheric trace gas profiles: case studies on the profile retrieval of $\mathrm{O} 4$ and $\mathrm{BrO}$, Atmos. Meas. Tech., 4, 1241-1260, https://doi.org/10.5194/amt-4-1241-2011, 2011.

Pratt, K. A., Custard, K. D., Shepson, P. B., Douglas, T. A., Pöhler, D., General, S., Zielcke, J., Simpson, W. R., Platt, U., Tanner, D. J., Gregory Huey, L., Carlsen, M., and Stirm, B. H.: Photochemical production of molecular bromine in Arctic surface snowpacks, Nat. Geosci., 6, 351-356, https://doi.org/10.1038/ngeo1779, 2013.

Richter, A., Wittrock, F., Eisinger, M., and Burrows, J. P.: GOME Observations of Tropospheric BrO in Northern Hemispheric Spring and Summer 1997, Geophys. Res. Lett., 25, 2683-2686, 1998.

Salawitch, R. J., Canty, T., Kurosu, T., Chance, K., Liang, Q., da Silva, A., Pawson, S., Nielsen, J. E., Rodriguez, J. M., Bhartia, P. K., Liu, X., Huey, L. G., Liao, J., Stickel, R. E., Tanner, D. J., Dibb, J. E., Simpson, W. R., Donohoue, D., Weinheimer, A., Flocke, F., Knapp, D., Montzka, D., Neuman, J. A., Nowak, J. B., Ryerson, T. B., Oltmans, S., Blake, D. R., Atlas, E. L., Kinnison, D. E., Tilmes, S., Pan, L. L., Hendrick, F.,
Van Roozendael, M., Kreher, K., Johnston, P. V., Gao, R. S., Johnson, B., Bui, T. P., Chen, G., Pierce, R. B., Crawford, J. H., and Jacob, D. J.: A new interpretation of total column BrO during Arctic spring, Geophys. Res. Lett., 37, L21805, https://doi.org/10.1029/2010GL043798, 2010.

Schmidt, J. A., Jacob, D. J., Horowitz, H. M., Hu, L., Sherwen, T., Evans, M. J., Liang, Q., Suleiman, R. M., Oram, D. E., Le Breton, M., Percival, C. J., Wang, S., Dix, B., and Volkamer, R.: Modeling the observed tropospheric BrO background: Importance of multiphase chemistry and implications for ozone, OH, and mercury, J. Geophys. Res.-Atmos., 121, 11819-11835, https://doi.org/10.1002/2015JD024229, 2016.

Schroeder, W. H., Anlauf, K. G., Barrie, L. A., Lu, J. Y., Steffen, A., Schneeberger, D. R., and Berg, T.: Arctic springtime depletion of mercury, Nature, 394, 331-332, https://doi.org/10.1038/28530, 1998.

Shepson, P.: Studies of the Production of Molecular Halogens in Arctic Snowpacks and on Sea Ice Surfaces, Arctic Data Center, https://arcticdata.io/catalog/\#view/urn:uuid: cf8576c7-595a-4774-b275-0e979152f7eb (last access: 20 June 2017), 2014.

Sihler, H., Platt, U., Beirle, S., Marbach, T., Kühl, S., Dörner, S., Verschaeve, J., Frieß, U., Pöhler, D., Vogel, L., Sander, R., and Wagner, T.: Tropospheric BrO column densities in the Arctic derived from satellite: retrieval and comparison to ground-based measurements, Atmos. Meas. Tech., 5, 27792807, https://doi.org/10.5194/amt-5-2779-2012, 2012.

Simpson, W. R., Carlson, D., Hönninger, G., Douglas, T. A., Sturm, M., Perovich, D., and Platt, U.: First-year sea-ice contact predicts bromine monoxide $(\mathrm{BrO})$ levels at Barrow, Alaska better than potential frost flower contact, Atmos. Chem. Phys., 7, 621-627, https://doi.org/10.5194/acp-7-621-2007, 2007a.

Simpson, W. R., von Glasow, R., Riedel, K., Anderson, P., Ariya, P., Bottenheim, J., Burrows, J., Carpenter, L. J., Frieß, U., Goodsite, M. E., Heard, D., Hutterli, M., Jacobi, H.-W., Kaleschke, L., Neff, B., Plane, J., Platt, U., Richter, A., Roscoe, H., Sander, R., Shepson, P., Sodeau, J., Steffen, A., Wagner, T., and Wolff, E.: Halogens and their role in polar boundary-layer ozone depletion, Atmos. Chem. Phys., 7, 4375-4418, https://doi.org/10.5194/acp7-4375-2007, 2007b.

Simpson, W. R., Brown, S. S., Saiz-Lopez, A., Thornton, J. A., and von Glasow, R.: Tropospheric Halogen Chemistry: Sources, Cycling, and Impacts, Chem. Rev., 115, 4035-4062, https://doi.org/10.1021/cr5006638, 2015.

Simpson, W. R., Peterson, P. K., Frieß, U., Sihler, H., Lampel, J., Platt, U., Moore, C., Pratt, K., Shepson, P., Halfacre, J., and Nghiem, S. V.: Horizontal and vertical structure of reactive bromine events probed by bromine monoxide MAX-DOAS spectroscopy, Atmos. Chem. Phys. Discuss., https://doi.org/10.5194/acp-2017-187, in review, 2017.

Smirnov, N. V.: On the estimation of the discrepancy between empirical curves of distribution for two independent samples, Bull Math. Univ. Moscou, 2, 1939.

Steffen, A., Douglas, T., Amyot, M., Ariya, P., Aspmo, K., Berg, T., Bottenheim, J., Brooks, S., Cobbett, F., Dastoor, A., Dommergue, A., Ebinghaus, R., Ferrari, C., Gardfeldt, K., Goodsite, M. E., Lean, D., Poulain, A. J., Scherz, C., Skov, H., Sommar, J., and Temme, C.: A synthesis of atmospheric mercury depletion event 
chemistry in the atmosphere and snow, Atmos. Chem. Phys., 8, 1445-1482, https://doi.org/10.5194/acp-8-1445-2008, 2008.

Stein, A. F., Draxler, R. R., Rolph, G. D., Stunder, B. J. B., Cohen, M. D., and Ngan, F.: NOAA's HYSPLIT Atmospheric Transport and Dispersion Modeling System, B. Am. Meteorol. Soc., 96, 2059-2077, https://doi.org/10.1175/BAMS-D-14$00110.1,2015$.

Theys, N., Van Roozendael, M., Errera, Q., Hendrick, F., Daerden, F., Chabrillat, S., Dorf, M., Pfeilsticker, K., Rozanov, A., Lotz, W., Burrows, J. P., Lambert, J.-C., Goutail, F., Roscoe, H. K., and De Mazière, M.: A global stratospheric bromine monoxide climatology based on the BASCOE chemical transport model, Atmos. Chem. Phys., 9, 831-848, https://doi.org/10.5194/acp-9831-2009, 2009.

Theys, N., Van Roozendael, M., Hendrick, F., Yang, X., De Smedt, I., Richter, A., Begoin, M., Errera, Q., Johnston, P. V., Kreher, K., and De Mazière, M.: Global observations of tropospheric BrO columns using GOME-2 satellite data, Atmos. Chem. Phys., 11, 1791-1811, https://doi.org/10.5194/acp-11-1791-2011, 2011.
Toyota, K., McConnell, J. C., Staebler, R. M., and Dastoor, A. P.: Air-snowpack exchange of bromine, ozone and mercury in the springtime Arctic simulated by the 1-D model PHANTAS Part 1: In-snow bromine activation and its impact on ozone, Atmos. Chem. Phys., 14, 4101-4133, https://doi.org/10.5194/acp14-4101-2014, 2014.

Wagner, T. and Platt, U.: Satellite mapping of enhanced $\mathrm{BrO}$ concentrations in the troposphere, Nature, 395, 486-490, https://doi.org/10.1038/26723, 1998.

Wagner, T., Ibrahim, O., Sinreich, R., Frieß, U., von Glasow, R., and Platt, U.: Enhanced tropospheric BrO over Antarctic sea ice in mid winter observed by MAX-DOAS on board the research vessel Polarstern, Atmos. Chem. Phys., 7, 3129-3142, https://doi.org/10.5194/acp-7-3129-2007, 2007.

Yang, X., Pyle, J. A., Cox, R. A., Theys, N., and Van Roozendael, M.: Snow-sourced bromine and its implications for polar tropospheric ozone, Atmos. Chem. Phys., 10, 7763-7773, https://doi.org/10.5194/acp-10-7763-2010, 2010. 